\title{
The Effect of the Liquidity Management on Profitability in the Jordanian Commercial Banks
}

\author{
Ali Sulieman Alshatti ${ }^{1}$ \\ ${ }^{1}$ Dept. of Banking and Finance sciences, Philadelphia University, Jordan \\ Correspondence: Ali Sulieman Alshatti, Dept. of Banking and Finance sciences, Philadelphia University, Jordan. \\ Tel: 962-795-630-502. E-mail: alialshati2008@gmail.com \\ Received: October 30, 2014 \\ Accepted: November 18, 2014 \\ Online Published: December 20, 2014 \\ doi:10.5539/ijbm.v10n1p62 \\ URL: http://dx.doi.org/10.5539/ijbm.v10n1p62
}

\begin{abstract}
This paper seeks at investigating the effect of liquidity management on profitability in the Jordanian commercial banks during the time period (2005-2012). Thirteen banks have been chosen to express on the whole Jordanian commercial banks. The liquidity indicators are investment ratio, Quick ratio, capital ratio, net credit facilities/ total assets and liquid assets ratio, while return on equity (ROE) and return on assets (ROA) were the proxies for profitability. Augmented Dickey Fuller (ADF) stationary test model was used to test for a unit root in a time series of the research variables and then testing hypothesis by using regression analysis. The empirical results show that an increase in the quick ratio and the investment ratio of the available funds leads to an increase in the profitability, while an increase in the capital ratio and the liquid assets ratio leads to decrease in the profitability of the Jordanian commercial banks. The researcher recommends that there is a need for an optimum utilization of the available liquidity in a various aspects of investment in order to increase the banks' profitability, and banks should adopt a general framework of liquidity management to assure sufficient liquidity for executing their operations more efficiently, and they should initiate an analytical study of the evolution rates of liquidity and their ability to achieve a balance between sources and uses of funds.
\end{abstract}

Keywords: liquidity, profitability, ROE, ROA, acid liquid assets

\section{Introduction}

The liquidity in the commercial bank represents the ability to fund its obligations by the contractor at the time of maturity, which includes lending and investment commitments, withdrawals, deposits, and accrued liabilities (Amengor, 2010).

Liquidity management takes one of two forms based on the definition of liquidity. One type of liquidity refers to the ability to trade an asset, such as a stock or bond, at its current price. The other definition of liquidity applies to large organizations, such as financial institutions. Banks are often evaluated on their liquidity, or their ability to meet cash and collateral obligations without incurring substantial losses. In either case, liquidity management describes the effort of investors or managers to reduce liquidity risk exposure. (Investopedia).

\subsection{Research Problem}

The commercial banks play their mediation role by absorbing financial surpluses from their holders (depositors) and put them at the disposal of investors (borrowers) to be directed towards various investment channels. This investment activity carried out by the bank is hardly devoid of risks and problems, because the bank is seeking to maximize its expected profits on these investments, and this requires optimum utilization of the available resources, since the bank is exposed at any moment to meet the obligations of its clients and depositors who want to withdraw their savings, and so the bank should be ready to meet these demands at any time.

The problem arises when the Bank is not able to meet these demands, especially those unexpected ones, which may embarrass the bank with its clients and may lose their trust over the time, in light of the intensive competition in the banking sector resulting from the increasing number of local banks, as well as intensive competition from the foreign banks that work in the local banking market.

Therefore, each commercial bank has to work to maximize its profits, and at the same time be able to meet the financial requirements of its depositors by holding a sufficient amount of liquidity, in order to achieve a balance between the profitability and liquidity. Banks should determine the optimal amount of cash that enable them in 
achieving balance between profitability and liquidity together, because each level of liquidity has a different effect on the levels of profitability, and the problem arises when the commercial banks try to maximize their profit at the expense of neglecting the liquidity effect, which may cause a technical and financial hardship with the consequent withdraw of deposits. Therefore, this research seeks to answer the following questions:

- Does the efficient liquidity management affect the banks' profitability?

- How do the liquidity indicators affect the banks' profitability?

- What are the limitations that may hinder the achievement of the required balance between liquidity and profitability, and how to overcome these limitations?

\subsection{Research Objective}

This paper aims at investigating the impact of the banking liquidity management on profitability in the Jordanian commercial banks, considering their need to keep a highest balance between liquidity and profitability at the same time. Therefore, this research will focus on identifying the most important indicators of the liquidity management, investigate the effect of each indicator on the banks' profitability, identify the effect of the liquidity management as a whole on profitability in the commercial banks, and lastly to suggest a recommendations needed to achieve the required consensus between liquidity and profitability in these banks.

\subsection{Research Design}

The paper consists of the following parts: part two presents a literature review on the effect of the liquidity management on profitability in the commercial banks and the research hypotheses. Part three determines the research methodologies. While part four represents the analysis part of the research. Finally, part five reviews the findings and the conclusion of the research analysis. .

\section{Literature Review}

This research presents some of the previous studies about the effect of liquidity management on banks' profitability, and an overview about the Jordanian economy.

\subsection{Theoretical Literature}

This part presents some theoretical aspects related to banks liquidity concept, the need for liquidity, theories of liquidity management, banks profitability and its measures, as follows.

\subsubsection{Banks Liquidity Concept}

Bank liquidity means the ability to meet financial obligations as they come due. Liquidity in Commercial Bank means the bank's ability to finance all its contractual obligations when due, and these obligations can include lending, investment and withdrawal of deposits and maturity of liabilities, which happen in the normal course of the Bank actions (Amengor, 2010).

\subsubsection{Theories of Liquidity Management}

There are a number of liquidity management theories, as follows:

1). Anticipated Income Theory

According to this theory bankers again began to look at their loan portfolio as a source of liquidity. The anticipated income theory encouraged bankers to treat long-term loans as potential sources of liquidity. How can a banker consider a mortgage loan as a source of liquidity when, typically, it has such a long maturity? Using the anticipated income theory, these loans are typically paid off by the borrower in a series of installments. Viewed in this way, the bank's loan portfolio provides the bank with continuous flow of funds that adds to the bank's liquidity. Moreover, even though the loans are long term, in a liquidity crisis the bank can sell the loans to obtain needed cash in secondary markets. (thefutureofmoney)

\section{2). Shiftability Theory}

Shiftability is an approach to keep banks liquid by supporting the shifting of assets. When a bank is short of ready money, it is able to sell its assets to a more liquid bank. The approach lets the system of banks run more efficiently: with fewer reserves or investing in long-term assets. Under shiftability, the banking system tries to avoid liquidity crises by enabling banks to always sell or repo at good prices (en.wikipedia.org.)

\section{3). Liability Management Theory}

This theory states that there is no need to follow old liquidity norms like maintaining liquid assets, liquid investments etc., banks have focused on liabilities side of the balance sheet (scribd.com). 
According to this theory, banks can satisfy liquidity needs by borrowing in the money and capital markets. The fundamental contribution of this theory was to consider both sides of a bank's balance sheet as sources of liquidity (Emmanuel, 1997).

\section{4). Commercial Loan Theory}

This theory states that the liquidity of the commercial bank achieved automatically through self-liquidation of the loan, which being granted for short periods and to finance the working capital, where borrowers refund the borrowed funds after completion of their trade cycles successfully. According to this theory, the banks do not lend money for the purposes of purchasing real estate or consumer goods or for investing in stocks and bonds, due to the length of the expected payback period of these investments, where this theory is proper for traders who need to finance their specific trading transactions and for short periods (Emmanuel, 1997).

\subsubsection{The Concept of Banks Profitability}

Bank profitability is the ability of a bank to generate revenue in excess of cost, in relation to the bank's capital base. A sound and profitable banking sector is better able to withstand negative shocks and contribute to the stability of the financial system. (Brissimis, Athanasoglou, and Delis, 2005).

Profitability in general is a relationship between the profits generated by the enterprise and investments that contributed to the achievement of these profits, and profitability ratios measure the efficiency with which a company turns business activity into profits. Profit margins assess the ability to turn revenue into profits. Return on assets measures the ability to use assets to produce net income. Return on equity compares the net income to shareholder equity (.chron.com.).

\subsubsection{Liquidity Measurement}

Liquidity is a measure of the ability and ease with which assets can be converted to cash. Liquid assets are those that can be converted to cash quickly if needed to meet financial obligations; examples of liquid assets generally include cash, central bank reserves, and government debt. To remain viable, a financial institution must have enough liquid assets to meet its near-term obligations, such as withdrawals by depositors. (federalreserve.gov).

The main measures of liquidity current ratio, capital ratio, cash ratio, quick ratio, investment ratio.

\subsubsection{Assessment the Bank's Profitability}

In order to determine the extent of the bank ability to make profits from its invested money, there are different financial ratios related to both the owners and depositors. The following two ratios are the most important earnings ratios used in assessing the bank profitability (Taha, 1999, p 190-191).

\section{1). Return on assets (ROA)}

This ratio measures the efficiency of a firm at generating profits from each unit of shareholder equity, also known as net assets or assets minus liabilities. ROE shows how well a company uses investments to generate earnings growth. (wikipedia.org)

\section{2). Return on Equity (ROE)}

This ratio measures the efficiency of a firm at generating profits from each unit of shareholder equity, also known as net assets or assets minus liabilities. ROE shows how well a company uses investments to generate earnings growth. (wikipedia.org)

\subsection{Empirical Review}

The effect of liquidity management on banks' profitability has been studied by a number of researchers; here is some review of them.

Adebayo et al. (2011) examined liquidity management and commercial banks' profitability in Nigeria. Findings of this study indicate that there is significant relationship between liquidity and profitability. That means profitability in commercial banks is significantly influenced by liquidity and vice versa.

Saleem and Rehman (2011) sought to reveal the relationship between liquidity and profitability. The main results of the study demonstrate that each ratio (variable) has a significant effect on the financial positions of enterprises with differing amounts and that along with the liquidity ratios in the first place. Profitability ratios also play an important role in the financial positions of enterprises.

Arif (2012) tested liquidity risk factors and assessed their impact on (22) of Pakistani banks during the period (2004-2009). Findings of the study indicate that there is a significant impact of liquidity risk factors on the banks 
profitability, where an increase in deposits lead to increasing in the bank's profitability in terms of reducing dependence on the central bank in meeting the customers' obligations, and profitability is negatively affected by the allocation of non-performing loans and liquidity gap.

Charity (2012) examined the impact of liquidity performance in commercial using First Bank of Nigeria Plc as case study. Findings indicate that there was a positive relationship between liquidity management and the existence of any banks.

Agbada and Osuji (2013) examined empirically the effect of efficient liquidity management on banking performance in Nigeria. Findings from the empirical analysis were quite robust and clearly indicate that there is significant relationship between efficient liquidity management and banking performance and that efficient liquidity management enhance the soundness of bank.

Al-Tamimi and Obeidat (2013) identified the most important variables which affect the Capital Adequacy of Commercial Banks of Jordan in Amman Stock Exchange for the period from 2000 -2008. The study shows that there is a statistically significant positive correlation between the degree of capital adequacy in commercial banks and the factors of liquidity risk, and the return on assets, and there is an inverse relationship not statistically significant between the degree of capital adequacy in commercial banks and factors of the capital risk, credit risk, and the rate of force- revenue.

Ibe (2013) examined the effect of liquidity management on the profitability of banks in Nigeria. He found that liquidity management is indeed a critical issue in the banking sector of Nigeria.

Lartey et al. (2013) sought to find out the relationship between the liquidity and the profitability of banks listed on the Ghana Stock Exchange. It was found that for the period 2005-2010, both the liquidity and the profitability of the listed banks were declining. Again, it was also found that there was a very weak positive relationship between the liquidity and the profitability of the listed banks in Ghana.

Moein Addin et al (2013) investigated the relationship between modern liquidity indices and stock return in companies listed on Tehran Stock Exchange. Results indicated that there was a positive and significant relationship between comprehensive liquidity index and stock returns while there was no significant relationship between the index of cash conversion cycle as well as net liquidity balance and sock returns.

Almazari (2014) investigated the internal factors that have an effect on profitability in Saudi and Jordanian banks. He found that there is a positive correlation between profitability measured by ROA of Saudi and Jordanian banks with some liquidity indicators, as well as there is a negative correlation with other liquidity indicators between profitability measured by ROA of Saudi and Jordanian banks

\subsection{Jordanian Commercial Banks}

The banking sector in Jordan distributed on three types of banks, namely:

- The commercial banks.

- The Islamic banks.

- The foreign banks in Jordan.

The Jordanian Commercial Banks consist of (13) Banks, as follows:

Table 1. Jordan commercial banks

\begin{tabular}{|c|c|c|c|}
\hline Bank No. & Bank name & Bank No. & Bank name \\
\hline & The Arab bank & & The Housing bank \\
\hline & Jordan Kuwait bank & & Jordan national bank \\
\hline & Cairo Amman bank & & Bank of Jordan \\
\hline & Societe Generale Banque & & Union bank \\
\hline & Investment Bank & & Capital Bank of Jordan \\
\hline & ABC Bank & & Arab Jordan Investment Bank \\
\hline & Jordan commercial bank & ---- & -------------------------------------- \\
\hline
\end{tabular}

\subsection{Research Hypotheses}

The research hypotheses have been formulated as follows:

H01: The banking liquidity management has no significant effect on banks' profitability. 
H02: The investment ratio has no significant effect on banks' profitability.

H03: The Net credit facilities/Total assets ratio has no significant effect on banks' profitability.

H04: The capital ratio has no significant effect on banks' profitability.

H05: The liquidity ratio has no significant effect on banks' profitability.

H06: The quick ratio has no significant effect on banks' profitability.

\subsection{What Distinguishes This Research from Other Previous Researches?}

This research tries to improve on the published studies about the effect of liquidity management on banks' profitability. It also contributes to the existing literature by providing a new addition to the previous literature about the effect of liquidity management on profitability in the Jordanian commercial banks.

\section{Research Methodology}

\subsection{Research Data}

This paper seeks at investigating the impact of the liquidity management on profitability in the (13) Jordanian commercial banks during the time period (2005-2012). By applying the data issued by Amman Stock Market about the Jordanian commercial banks as a panel type study.

\subsection{Research Models}

The following two models represent the research models:

$$
\begin{aligned}
& Y 1=a 0+a 1 \times 1+a 2 \times 2+a 3 \times 3+a 4 \times 4+a 5 \times 5 \\
& Y 2=b 0+b 1 \times 1+b 2 \times 2+b 3 \times 3+b 4 \times 4+b 5 \times 5
\end{aligned}
$$

Where: Y1, Y2: represents the bank's profitability measured by ROE, ROA respectively.

$\mathrm{X} 1$ : Investment ratio $=$ Net credit facilities $/$ Total deposits.

X2: Net credit facilities / Total assets.

$\mathrm{X} 3$ : Capital ratio $=\mathrm{Capital} /$ Total assets.

$\mathrm{X} 4$ : Liquid ratio $=$ Acid liquid assets $/$ Total assets

X5: Quick- Acid ratio $=($ Current assets- Inventory $) /$ Current liabilities.

a1, a2, a3, a4, and a5: Represent the values of the variables coefficients of the first model.

Where b1, b2, b3, b4, and b5: Represent the values of the variables coefficients of the second model.

$\mathrm{a} 0$, b0: represent the values of the vertical section.

The first model measures the effect of the liquidity management indicators on profitability in the Jordanian commercial banks, where return on equity (ROE) was the proxy for profitability.

The second model measures the effect of the liquidity management indicators on profitability in the Jordanian commercial banks, where return on assets (ROA) was the proxy for profitability.

\subsection{Variables Definition}

The liquidity management has been measured by the following ratios:

Investment ratio $=$ Net credit facilities $/$ Total deposits.

Net credit facilities / Total assets.

Capital ratio $=$ Capital $/$ Total assets

Liquid ratio $=$ Acid liquid assets $/$ Total assets.

Quick- Acid ratio $=($ Current assets- Inventory $) /$ Current liabilities.

The banks' profitability (the dependent variable) has been measured by the two ratios, Return on Equity (ROE) and Return on Assets (ROA). 
Table 2. Variables definition \& measurement units

\begin{tabular}{lll}
\hline Variables symbol & Measurement unit & Variables explanation \\
\hline IR & Investment Ratio & Net credit facilities / Total deposits \\
NCF/TA & Net credit facilities/ Total assets & Net credit facilities / Total assets \\
CR & Capital ratio & Capital / Total assets \\
LR & Liquid ratio & Acid liquid assets / Total assets \\
QR & Quick-Acid ratio & Current assets - Inventory / Current liabilities \\
ROE & Return on Equity & Net Income/ Owners Equity \\
ROA & Return on Assets & Net Income/ Total Assets \\
\hline
\end{tabular}

\subsection{Research Analysis}

This paper applies the quantitative approaches and ratios analysis to investigate the impact of liquidity management on banks' profitability during the time period (2005-2012), and that includes ratio analysis of the profitability and liquidity indicators, cross sectional analysis, regression analysis, and (F-Fisher) test, on the panel data issued by Amman Stock Market about the Jordanian commercial banks.

\subsection{Statistical Analysis and Interpretation}

Stationary Test of the First Model:

The results below show that the rejection of the null hypothesis about the variables stationarity of the first model at the first difference.

Table 3. The stationary results of the 1 st model

\begin{tabular}{lccc}
\hline Variables & ADF Statistics & P- Value & Order of Integration \\
\hline Y1 & 16.5402 & 0.0000000 & $1(0)$ \\
$\mathrm{X} 1$ & 1.72769 & 0.0000420 & $1(0)$ \\
$\mathrm{X} 2$ & 4.74167 & 0.0000000 & $1(0)$ \\
$\mathrm{X} 3$ & 9.14883 & 0.0000000 & $1(0)$ \\
$\mathrm{X} 4$ & 4.82969 & 0.0000000 & $1(0)$ \\
$\mathrm{X} 5$ & 3.51313 & 0.0000002 & $1(0)$ \\
\hline
\end{tabular}

Source: Author computation from computer output.

Stationary Test of the Second Model:

The results below show that the rejection of the null hypothesis about the variables stationarity of the second model at the first difference.

Table 4: The stationary results of the 2nd model:

\begin{tabular}{crcc}
\hline Variables & ADF Statistics & P- Value & Order of Integration \\
\hline Y1 & 3.4521 & 0.0000000 & $1(0)$ \\
X1 & 8.5464 & 0.0000420 & $1(0)$ \\
X2 & 4.7694 & 0.0000000 & $1(0)$ \\
X3 & 2.2720 & 0.0000000 & $1(0)$ \\
X4 & 4.4326 & 0.0000000 & $1(0)$ \\
X5 & 3.0464 & 0.0000002 & $1(0)$ \\
\hline
\end{tabular}

Source: Author computation from computer output.

\section{Research Models Suitability}

By using the (F-Fisher) test, and applying the analysis output, where the (Sig. F) of the two models is less than $5 \%$, concluding that the research models are appropriate for testing the effect of liquidity management on banks' profitability. While the analysis output shows that $76 \%$ of the change in ROE is explained by the independent 
variables of the first model, and $66 \%$ of the change in ROA is explained by the independent variables of the second model.

The correlation test

The correlation analysis outputs show that the significant of the correlation value is less than $5 \%$ means that there is correlation between liquidity management and banks' profitability.

Hypothesis Testing:

The following two models used to test the impact of liquidity management on banks' profitability:

$$
\begin{aligned}
& Y 1=a \pm a 1(X 1) \pm a 2(X 2) \pm a 3(X 3) \pm a 4(X 4) \pm a 5(X 5) \\
& Y 2=b \pm b 1(X 1) \pm b 2(X 2) \pm b 3(X 3) \pm b 4(X 4) \pm b 5(X 5)
\end{aligned}
$$

Test results of the research hypotheses:

The hypotheses test shows the results as follows:

1). the investment ratio has a significant positive impact on profitability of the Jordanian commercial banks.

2). the credit facilities divided by total assets ratio has a significant negative impact on profitability of the Jordanian commercial banks.

3). the capital ratio has a significant negative impact on profitability of the Jordanian commercial banks when measured by ROE, and a positive impact when measured by ROA.

4). the liquid ratio has a significant negative impact on profitability of the Jordanian commercial banks.

5). the quick ratio has a significant positive impact on profitability of the Jordanian commercial banks.

Determining the coefficients values of the research models:

The two tables below show that the coefficient values of the two models respectively.

Table 5. Coefficient values of the first model

\begin{tabular}{lll}
\hline Variables & Coefficients & Sig. T \\
\hline X1 & +0.126 & 0.0003 \\
X2 & -0.262 & 0.0038 \\
X3 & -0.215 & 0.0409 \\
X4 & -0.330 & 0.0000 \\
X5 & +0.153 & 0.0023 \\
Constant & +0.216 & 0.0000 \\
\hline
\end{tabular}

Source: Author computation from computer output.

Table 6 Coefficient values of the second model

\begin{tabular}{lll}
\hline Variables & Coefficients & Sig. T \\
\hline $\mathrm{X} 1$ & +0.010 & 0.0081 \\
$\mathrm{X} 2$ & -0.022 & 0.0056 \\
$\mathrm{X} 3$ & +0.058 & 0.0502 \\
$\mathrm{X} 4$ & -0.054 & 0.0000 \\
$\mathrm{X} 5$ & +0.027 & 0.0000 \\
Constant & +0.016 & 0.0053 \\
\hline
\end{tabular}

Source: Author computation from computer output.

By applying the coefficient values in the two tables above, the research equations will be formulated as follows:

$$
\begin{aligned}
& Y 1=0.216+0.126 X 1-0.262 X 2-0.215 X 3-0.330 X 4+0.153 X 5 \\
& Y 2=0.016+0.010 X 1-0.022 X 2+0.058 X 3-0.054 X 4+0.027 X 5
\end{aligned}
$$

The first equation indicates that the profitability as measured by return on equity is affected positively by the investment and quick ratios, and negatively by the other variables. 
While the second equation indicates that the profitability as measured by return on assets is affected positively by the investment ratio, Net credit facilities/ Total assets, and the quick ratio, but the profitability is negatively affected by the two other variables.

\section{Findings}

This paper seeks at investigating the effect of the banking liquidity management on profitability in the Jordanian commercial banks, through identifying the indicators of banking liquidity and profitability during the time period (2005-2012).

The review of the preliminary figures showed that there is a lack of uniformity in these figures during the research period, and the analysis output show that some of liquidity indicators effect positively on the profitability of these banks, and this result is consistent with the findings mentioned by (Bourke, 1989) where he found in his study that the banking liquid assets effect on profitability, which was conducted on the 90 banks in Europe, North America, and Australia during the period (1972-1981).

It is noted that an increase in the investment ratio, as well as in the quick ratio leads to an increase in profitability by rising the return on equity (ROE), and that means the profitability in the commercial banks increases with an increase in the quick ratio and the investment ratio, this result is consistent with the findings of (Adebayo et al, 2011) in their research, and is contrary to the conclusion reached in the study of (Shahatiet, 2011).

The results also indicate that a decrease in the percent of the invested funds out of the total available funds, as well as a decrease in capital, and in Acid liquid assets, lead to increase in profitability in the Jordanian Commercial Banks when measured by ROE, but an increase in the capital ratio leads to increase in profitability as measured by ROA.

The researcher notes that, decreasing in the percent of invested funds as well as in the Bank capital contribute in increasing profitability in the Jordanian commercial banks, this result does not correspond with the logic which indicates that an increase in invested funds and in capital leads to an increase in profitability. While the result of decreasing in the percent of Acid liquid assets leads to increase in banks profitability, is logical and compatible with the principle of tradeoff between liquidity and profitability (decreasing in the liquid assets leads to a decrease in liquidity and at the same time leads to an increase in profitability).

\section{Summary and Conclusion}

This research aims at investigating empirically the effect of liquidity management on profitability of Jordanian commercial banks, and how can these banks keep balance between liquidity and profitability.

Based on the research findings, the researcher concluded that, there is an effect of the liquidity management on profitability in the Jordanian commercial banks as measured by ROE or ROA, where the effect of the investment ratio and quick ratios on the profitability is positive when measured by ROE, and the effect of capital ratio on profitability is positive as measured by ROA, and the effect of the other independent variables on the two measures of profitability (ROE and ROA) is negative, the researcher thinks that this negative effect is due to the increased volume of untapped deposits at the Jordanian commercial banks.

Consequently, the researcher recommends that there is a need to invest the excess of liquidity available at the banks, in a various aspects of investments in order to increase the banks' profitability and to get benefits from the time value of the available money, also the Jordanian commercial banks should adopt a general framework for liquidity management to assure a sufficient liquidity for executing their works efficiently, and there is a need to make an analytical study of the liquidity evolution rates to assess the banks' ability to achieve a balance between sources and uses of funds, the banks need to adopt of a scientific methods in detection of the strengths and weaknesses points of liquidity, especially in light of the sudden circumstances that may be exposed by banks.

\section{References}

Adebayo, M., Adeyanju, D., \& Olabode, S. (2011). Liquidity Management and Commercial Banks' Profitability in Nigeria. Research Journal of Finance and Accounting, 2(7/8). Retrieved from http://www.iiste.org

Al Nimer, M., Warrad, L. and Al Omari, R. 2013. "The impact of liquidity on Jordanian banks profitability through return on assets. Interdisciplinary Journal of contemporary Research in Business, 5(7). Retrieved from http://journal-archieves36.webs.com

Almazari, A. A. (2014). Impact of Internal Factors on Bank Profitability: Comparative Study between Saudi Arabia and Jordan. Journal of Applied Finance \& Banking, 4(1), 125-140. Retrieved from http://www.scienpress.com 
Almumani, M. A. (2013). Liquidity Risk Management: A Comparative Study between Saudi and Jordanian Banks. Interdisciplinary Journal of Research in Business, 3(2), 1-10. Retrieved from http://www.idjrb.com

Al-Tamimi, K., \& Obeidat, S. (2013). Determinants of Capital Adequacy in Commercial Banks of Jordan an Empirical Study. International Journal of Academic Research in Economics and Management Sciences, 2(4). Retrieved from http://www.hrmars.com/journals

Amengor, E. C. (2010). Importance of Liquidity and Capital Adequacy to Commercial Banks. A Paper Presented at Induction Ceremony of ACCE, UCC Campus.

Anyanwu J. C. (1993). Monetary Economics Theory, Policy and Institutions (pp. 247-274). Onitsha: Hybrid Publishers Ltd.

Arif, A. (2012). Liquidity risk and performance of banking system, Journal of Financial Regulation and Compliance, 20(2), 182-195. http://dx.doi.org/10.1108/13581981211218342

Bourke, P. (1989). Concentration and other determinants of bank profitability in Europe, North America, and Australia. Journal of Banking \& Finance, 13, 65-79. http://dx.doi.org/10.1016/0378-4266(89)90020-4

Brissimis, S., Athanasoglou, P., \& Delis, M. (2005). Bank-specific, Industry-specific and Macroeconomic determinants of bank profitability. Working Paper-Bank of Greece, 25. Retrieved from http://www.bankofgreece.gr.

Emmanuel, N.R, (1997), Commercial Banking in an Era of Deregulation, Greenwood Publishing Group, 3rd Ed.

Christy, G. A., Clendenin, J. C., \& Dietrich, J. S. (1978). Introduction to Investments (McGraw-Hill series in finance).

Ibe, S. O. (2013). The Impact of Liquidity Management on the Profitability of Banks in Nigeria. Journal of Finance and Banking Management, 1(1), 37-48. Retrieved from http://www.aripd.org/jfbm

Investopedia. Available at: http://www.investopedia.com.

Lartey, V., Antwi, S., \& Boadi, E. (2013). The Relationship between Liquidity and Profitability of Listed Banks in Ghana. International Journal of Business and Social Science, 4(3), 48-56. Retrieved from http://ijbssnet.com/journals

Moein, A. M., Nayebzadeh, Sh., \& Pour, M. A. (2013). The Relationship between Modern Liquidity Indices and Stock Return in Companies Listed on Tehran Stock Exchange. Interdisciplinary Journal of Contemporary Research in Business, 5(4), 352-360. Retrieved from http://ijcrb.webs.com

Neuman, W. L. (2007). Basics of Social Research (2nd ed.). Boston: Allyn and Bacon.

Nwankwo, G. O. (1991). Bank management principles and practices. Lagos: Malthouse press ltd.

Nzzotta, S. M. (2004). Money, Banking and Finance: Theory and Practice. Owerri.

Raulett, J. (1977). Money and Banking, an introduction to analysis and policy (3rd ed.). Santa Barbara, Jones wiley and son.

Shahchera, M. (2012). The impact of liquidity asset on Iranian bank profitability. International conference on management, behavioral sciences and economic issues, Penang Malaysia. Retrieved from http://psrcentre.org

Spindt, P. A., \& Tarhan, V. (1980). Liquidity structure adjustment behavior of large money center banks. Journal of Money, Credit and Banking. Ohio State University Press. http://dx.doi.org/10.2307/1991772

Tabari, N. A., Ahmadi, M., \& Emami, M. (2013). The Effect of Liquidity Risk on the Performance of Commercial Banks. International Research Journal of Applied and Basic Sciences, 4(6), 1624-1631. Retrieved from http://www.irjabs.com

http://www.chron.com.

https://en.wikipedia.org

http://www.federalreserve.gov.

http://www.scribd.com.

http://thefutureofmoney.blogspot.com. 


\section{Copyrights}

Copyright for this article is retained by the author(s), with first publication rights granted to the journal.

This is an open-access article distributed under the terms and conditions of the Creative Commons Attribution license (http://creativecommons.org/licenses/by/3.0/). 